\title{
Woodland salamander responses to a shelterwood harvest-prescribed burn silvicultural treatment within Appalachian mixed-oak forests
}

\author{
Kathleen R. Mahoney ${ }^{\mathrm{a}, *}$, Kevin R. Russell ${ }^{\mathrm{a}}$, W. Mark Ford ${ }^{\mathrm{b}}$, Jane L. Rodrigue ${ }^{\mathrm{c}, 1}$, Jason D. Riddle ${ }^{\mathrm{a}}$, \\ Thomas M. Schuler ${ }^{\mathrm{d}}$, Mary Beth Adams ${ }^{\mathrm{d}, 2}$ \\ ${ }^{a}$ College of Natural Resources, University of Wisconsin-Stevens Point, Stevens Point, WI 54481, USA \\ ${ }^{\mathrm{b}}$ U.S. Geological Survey, Virginia Cooperative Fish and Wildlife Research Unit, Virginia Polytechnic Institute and State University, Blacksburg, VA 24061, USA \\ ${ }^{c}$ U.S. Forest Service, Northern Research Station, Princeton, WV 24740, USA \\ ${ }^{\mathrm{d}}$ U.S. Forest Service, Northern Research Station, Parsons, WV 26287, USA
}

\section{A R T I C L E I N F O}

\section{Article history:}

Received 11 August 2015

Received in revised form 24 September

2015

Accepted 26 September 2015

Available online 22 October 2015

\section{Keywords:}

Plethodon ochrophaeus

Plethodon glutinosus

Plethodon cinereus

Timber harvest

Prescribed fire

Central Appalachians

\begin{abstract}
A B S T R A C T
Forest management practices that mimic natural canopy disturbances, including prescribed fire and timber harvests, may reduce competition and facilitate establishment of favorable vegetative species within various ecosystems. Fire suppression in the central Appalachian region for almost a century has contributed to a transition from oak-dominated to more mesophytic, fire-intolerant forest communities. Prescribed fire coupled with timber removal is currently implemented to aid in oak regeneration and establishment but responses of woodland salamanders to this complex silvicultural system is poorly documented. The purpose of our research was to determine how woodland salamanders respond to shelterwood harvests following successive burns in a central Appalachian mixed-oak forest. Woodland salamanders were surveyed using coverboard arrays in May, July, and August-September 2011 and 2012. Surveys were conducted within fenced shelterwood-burn (prescribed fires, shelterwood harvest, and fencing to prevent white-tailed deer [Odocoileus virginianus] herbivory), shelterwood-burn (prescribed fires and shelterwood harvest), and control plots. Relative abundance was modeled in relation to habitat variables measured within treatments for mountain dusky salamanders (Desmognathus ochrophaeus), slimy salamanders (Plethodon glutinosus), and eastern red-backed salamanders (Plethodon cinereus). Mountain dusky salamander relative abundance was positively associated with canopy cover and there were significantly more individuals within controls than either shelterwood-burn or fenced shelterwood-burn treatments. Conversely, habitat variables associated with slimy salamanders and eastern red-backed salamanders did not differ among treatments. Salamander age-class structure within controls did not differ from shelterwood-burn or fenced shelterwood-burn treatments for any species. Overall, the woodland salamander assemblage remained relatively intact throughout the shelterwoodburn silvicultural treatment compared to previous research within the same study area that examined pre-harvest fire effects. However, because of the multi-faceted complexities of this specific silvicultural system, continued research is warranted that evaluates long-term, additive impacts on woodland salamanders within managed central Appalachian deciduous forests.
\end{abstract}

Published by Elsevier B.V.

\footnotetext{
This draft manuscript is distributed solely for purposes of scientific peer review. Its content is deliberative and pre-decisional, so it must not be disclosed or released by reviewers. Because the manuscript has not yet been approved for publication by the U.S. Geological Survey (USGS), it does not represent any official USGS finding or policy.

* Corresponding author.

E-mail address: kmahoneyr@gmail.com (K.R. Mahoney).

1 Present address: METI Corporation, 8600 Boeing Dr., El Paso, TX 79925, USA.

2 Present address: U.S. Forest Service, Northern Research Station, Morgantown, WV 26505, USA.
}

\section{Introduction}

Decades of fire suppression have contributed to a decline in oak (Quercus spp.) establishment and regeneration within the Appalachian region, favoring release of more shade-tolerant species including red maple (Acer rubrum) or fast-growing shadeintolerant species such as yellow poplar (Liriodendron tulipifera) (Nowacki and Abrams, 2008). In addition to vegetation encroachment, white-tailed deer (Odocoileus virginianus) herbivory and insect pest outbreaks are currently preventing oak reestablishment after timber harvest or natural mortality of canopy-dominant trees 
(Abrams, 1992). Fire coupled with canopy cover reduction following timber harvesting is thought to facilitate oak regeneration by providing suitable conditions for seedling establishment and reducing competition from less desirable woody species. Specifically, shelterwood harvests that reduce overstory canopy by approximately $50 \%$, followed by prescribed burns have resulted in successful oak regeneration and an associated decline in shade-tolerant vegetation in similar forest types (Brose and Van Lear, 1998). Although applying the shelterwood-burn silvicultural system to deciduous forests of the Appalachian region appears beneficial for restoring oak species and other fire-tolerant vegetation, prolonged absence of fire within these ecosystems may lead to unpredictable effects (Van Lear and Waldrop, 1989; Brose et al., 2001). In particular, repeated burning in forests that have developed over decades in the absence of fire and timber harvesting raises questions about impacts on forest floor dwelling vertebrates including woodland salamanders (Ford et al., 1999, 2010; Moorman et al., 2011).

Plethodontid salamanders rely on relatively cool, moist conditions that are associated with microhabitat characteristics indicative of mature, late-successional forests (Heatwole, 1962; Hairston, 1987; deMaynadier and Hunter, 1995; Petranka, 1998). Disturbances that reduce canopy cover, leaf litter, cover objects, or otherwise expose the forest floor to more light and higher temperatures are thought detrimental to woodland salamanders (deMaynadier and Hunter, 1995; Moorman et al., 2011). Accordingly, negative effects of timber harvest on Appalachian woodland salamanders are highest following canopy removal and associated ground disturbances after clearcutting (Ash, 1988; Petranka et al., 1993; Moorman et al., 2011). In contrast, timber harvest practices that retain some overstory (e.g., shelterwood, selection) exhibit lesser or no measurable effects on woodland salamander populations (Ford et al., 2000; Bartman et al., 2001; Homyack and Haas, 2009).

Despite abundant research investigating effects of timber harvest on woodland salamanders, responses of these species to natural or prescribed fire in deciduous and Appalachian forests remains poorly understood (Russell et al., 1999, 2004; Pilliod et al., 2003; Renken, 2006; Moorman et al., 2011). Woodland salamanders in the central Appalachians, where natural fires were less frequent and intense than in other areas of the United States (e.g., Coastal Plain pine forests), may respond negatively to the introduction of prescribed burning after decades without fire (Pilliod et al., 2003; Ford et al., 2010). In addition, salamanders may be more vulnerable to direct mortality from fire than other vertebrates because of their restricted mobility and susceptibility to desiccation (Russell et al., 1999; Renken, 2006). However, single and consecutive prescribed burns in deciduous forests of the eastern United States to date appear to negligibly affect woodland salamanders (Kirkland et al., 1996; Ford et al., 1999, 2010; Keyser et al., 2004; Greenberg and Waldrop, 2008).

The shelterwood-burn silvicultural system involves multiple treatments and stand entries that, in many cases, may take a decade or more to complete (Burns and Honkala, 1990). Each stand entry has the potential to negatively impact salamander assemblages individually or cumulatively (Moseley et al., 2008; Moorman et al., 2011). Previous studies have typically evaluated the individual impacts of shelterwood harvesting (Sattler and Reichenbach, 1998; Harpole and Haas, 1999; Bartman et al., 2001; Knapp et al., 2003; Homyack and Haas, 2009; Raybuck et al., 2015) or prescribed fire (Kirkland et al., 1996; Ford et al., 1999, 2010; Floyd et al., 2002; Raybuck et al., 2015). However, there is limited information on the combined impacts of both forest management practices (Keyser et al., 2004; O'Donnell et al., 2015). Also, many of these studies were conducted within 1-3 years of application (Sattler and Reichenbach, 1998; Harpole and Haas, 1999; Ford et al., 1999, 2010; Bartman et al., 2001; Pilliod et al., 2003; Raybuck et al., 2015), thereby not accounting for enduring impacts to salamander populations. Woodland salamanders are relatively long-lived species that may reproduce only every other year or longer (Duellman and Trueb, 1986; Hairston, 1987; Pilliod et al., 2003), and as a result, potential direct effects of silvicultural practices on salamanders or indirect effects from alterations in vegetation may take several years to become evident (Russell et al., 2004; Ford et al., 2010), especially when applying multiple forest management practices over time.

Evaluating woodland salamander responses for the duration of this complex silvicultural system will provide a unique opportunity to address the current lack of information regarding impacts of long-term, additive forest management practices on salamander populations in central Appalachian mixed-oak forests. The objective of our study was to determine how woodland salamanders respond to shelterwood harvests within a previously burned central Appalachian mixed-oak forest. Specifically, we evaluated whether post-harvest changes in habitat variables associated with woodland salamanders influence salamander relative abundance and age-class structure. We also evaluated long-term, additive impacts of shelterwood-burn treatments on salamanders by comparing our results to those of Ford et al. (2010), who assessed effects of consecutive prescribed fires on woodland salamanders at the same sites between 2001 and 2007.

\section{Methods}

Our study was conducted in the Fernow Experimental Forest, located within the Monongahela National Forest in Tucker County, West Virginia. The Fernow Experimental Forest consists of approximately 1900-ha managed by the USDA Forest Service Northern Research Station for long-term silviculture and hydrologic research. This area is within the unglaciated Allegheny Mountains section of the Appalachian Plateau Physiographic region at elevations of 530-1100 m (Adams et al., 2008). The Fernow Experimental Forest was extensively logged during 1903-1911 (Trimble, 1977). As a result of these activities, the forest is best described today as a second-growth mixed mesophytic hardwood type (Braun, 1950), containing a mix of species: northern red oak (Quercus rubra), chestnut oak (Quercus prinus), white oak (Quercus alba), shagbark hickory (Carya ovata), bitternut hickory (Carya cordiformis), yellow poplar, American beech (Fagus grandifolia), sugar maple (Acer saccharum), red maple, black gum (Nyssa sylvatica), and eastern hemlock (Tsuga canadensis).

Our research was conducted within the Canoe Run watershed and consisted of 240.20 -ha plots, including 14 on upper slopes and 10 on lower slopes. These plots were previously established for earlier studies evaluating the effects of two consecutive prescribed fires on oak regeneration (Schuler et al., 2010) and woodland salamander populations (Ford et al., 2010). The plots were generally on southwestern-facing aspects (180-325 $)$ with variation in elevation (600-775 m) and slope steepness (4-19\%). Upper slope sites were thinned 30 years ago to a $60-75 \%$ stocking level, whereas lower slopes remained fully stocked (Schuler and Miller, 1995). Twenty plots were burned using two prescribed fires. Poor weather conditions interrupted the first prescribed fire in April 2002 with only partial coverage on the upper slope. Lower slope plots were burned successfully the following spring in 2003 (Schuler et al., 2010). In April 2005, 20 lower and upper slope plots were burned a second time with adequate intensity and coverage to reduce small diameter tree stocking. Sites were burned using strip head fire with hand-held drip torches. Fires were generally of moderate or low intensity during all prescribed burns (Ford et al., 2010). Four plots remained as unburned controls with two 
each on upper and lower slopes. In addition, 10 of 20 burned plots (6 upper slope and 4 lower slope) were fenced for an ongoing study monitoring effects of white-tailed deer browsing on vegetation (Schuler et al., 2010). During the dormant season of 2009-2010, a shelterwood harvest reduced average overstory basal area from $33.29 \mathrm{~m}^{2}$ /ha to $14.23 \mathrm{~m}^{2} /$ ha (Schuler et al., 2012).

We used coverboard arrays (DeGraaf and Yamasaki, 1992) to survey woodland salamanders once in May, July, and AugustSeptember of 2011 and 2012. Arrays were constructed from 1-m² pieces of plywood cut into 9 identical square pieces following the same design as Ford et al. (2010). Coverboards were installed in March 2011 to allow them to weather prior to the first sampling period. Within each plot, three coverboard arrays were placed along the central axis of the plot, separated by $10-15 \mathrm{~m}$. Boards were placed in a square grid ( 3 boards $\times 3$ boards) with approximately $2.5 \mathrm{~cm}$ between each board to allow rainfall to weather the array.

During surveys each salamander captured was identified to species and we measured mass $(\mathrm{g})$, total length ( $\mathrm{mm})$, and snout-vent length $(\mathrm{mm})$. We classified each salamander as an adult or juvenile by its snout-vent length: juvenile mountain dusky salamanders were $\leqslant 30 \mathrm{~mm}$, juvenile eastern red-backed salamanders were $\leqslant 34 \mathrm{~mm}$, and juvenile slimy salamanders were $\leqslant 58 \mathrm{~mm}$ (Homyack and Haas, 2009). Each individual was marked by toeclipping with the same digit removed for each individual captured during a sampling period (Hero, 1989). Different digits were clipped in successive sampling periods so that salamanders received sample-specific marks. Air temperature $\left({ }^{\circ} \mathrm{C}\right)$, humidity (\%), and soil temperature $\left({ }^{\circ} \mathrm{C}\right)$ were measured at coverboard arrays during each survey (Forestry Suppliers hygro-thermometer).

Each coverboard array was the center of a $10 \times 10 \mathrm{~m}$ sampling plot where we measured abiotic and biotic habitat variables considered to be associated with plethodontid salamanders (Green and Pauley, 1987; Petranka, 1998). Within each plot, the species and diameter at breast height $(\mathrm{dbh})$ of all trees $\geqslant 10 \mathrm{~cm}$ dbh were recorded. We estimated overhead canopy closure above the coverboard array with a spherical concave densiometer (Lemmon, 1956). Vertical structure of understory vegetation was measured using a $2.5 \times 150 \mathrm{~cm}$ cover pole (Robel et al., 1970). To calculate the area of large woody debris (LWD) within each plot, we measured midpoint diameter, length within the plot, and decay class (1-5) of all woody debris that was $\geqslant 10 \mathrm{~cm}$ in diameter and flush against the forest floor (Maser et al., 1979; Sefidi and Mohadjer, 2010).

We sampled ground cover within $41-\mathrm{m}^{2}$ quadrats (Daubenmire, 1959) located at the center of the $10 \times 10 \mathrm{~m}$ plot and $1.5 \mathrm{~m}$ from the center in each cardinal direction. Percent ground cover was visually estimated for moss, herbaceous vegetation, grass, fern, leaf litter, emergent rock, fine woody debris, and bare ground. Litter depth and aspect were measured at each quadrat center. Aspect was linearized so that northeasterly aspects had the lowest values and southwesterly aspects had high values (Ford et al., 2002). Elevation, slope, and distance to stream were also calculated at each quadrat center (ESRI, 2012).

Because woodland salamanders are semi-fossorial much of the year, the ability to detect all individuals within an area is unlikely, so using unadjusted count data may not accurately index populations within an area over an extended period (Bailey et al., 2004). Therefore, we developed a priori candidate models based on factors that may influence differences in salamander detection probabilities. Our models included whether detection differed among treatments, differed among species, differed by a treatment-species interaction or remained constant across the study area. Using detection histories for each individual encountered within a single season, we calculated salamander detection probabilities with the Huggins Closed Capture model in Program Mark (Huggins, 1989;
White and Burnham, 1999). Models were evaluated using Akaike Information Criterion corrected for small sample size $\left(\mathrm{AIC}_{c}\right)$ (Burnham and Anderson, 2002), and the model with the largest $\mathrm{AIC}_{c}$ weight was chosen to calculate detection probabilities.

For 2011, we were unable to successfully model probabilities for individual salamander detection histories because of a small sample size ( $n=59$ individuals) and total lack of recaptures (Matthews et al., 2010). However in 2012 a larger sample size $(n=70)$ with recaptures (five eastern red-backed salamanders and one slimy salamander) enabled us to calculate probability of detection. The best model for salamander detection histories in 2012 was the constant model $\left(\mathrm{AIC}_{c}=184.94, \mathrm{AIC}_{c}\right.$ weight $\left.=0.48\right)$ with a detection of $0.28(S E=0.04)$. Because the probability of salamander detection did not differ among treatments or species in 2012 and we were unable to determine detection differences in 2011, we considered unadjusted counts directly proportional to salamander population size (relative abundance) and used raw counts in subsequent analyses (Williams et al., 2002; Riddle et al., 2008).

We used a one-way analysis of variance (ANOVA) to compare abiotic and biotic variables among control $(n=4)$, shelterwoodburn $(n=10)$, and fenced shelterwood-burn $(n=10)$ treatments. Means and standard errors were calculated for all variables among treatments. When an ANOVA resulted in a significant F-statistic $(P<0.05)$, we used Tukey's honestly significant difference (HSD) to determine which treatment means differed (SPSS, 2012 ${ }^{3}$ ).

An information-theoretic modeling approach (Burnham and Anderson, 2002) was used to identify relationships between habitat features and salamander relative abundance among control, shelterwood-burn, and fenced shelterwood-burn sites. Prior to model development, we eliminated redundant variables (Spearman $\left.r_{s} \geqslant 0.65\right)$ and retained 15 variables to use in models. We examined scatterplots, residual plots (Anderson-Darling tests $P<0.05$ ), and histograms to ensure that variables met assumptions of analyses (i.e., lack of colinearity, normality, linearity). When necessary, abiotic and biotic variables were square-root, log, or arcsine transformed to meet assumptions of normality. Because salamander relative abundance was derived from count data, the squareroot transformation was used to meet an assumption of normality and recaptures were excluded from subsequent analyses (Kuehl, 2000).

We developed a priori candidate models (Burnham and Anderson, 2002) that incorporated abiotic and biotic habitat variables measured around each array to explain salamander abundance. These models were based on a review of published literature on plethodontid salamander habitat relationships (Green and Pauley, 1987; deMaynadier and Hunter, 1995; Petranka, 1998). We specified 15 models: (1) "air temperature," (2) "basal area," (3) "canopy cover," (4) "cover objects" (LWD, \% fine woody debris, and \% leaf litter), (5) "decay class," (6) "fine woody debris," (7) "ground cover" (\% moss, \% herbaceous vegetation, \% fern, \% grass, \% leaf litter, and \% fine woody debris), (8) "landscape" (elevation and aspect), (9) "large woody debris," (10) "leaf litter," (11) "stream," (12) "timber harvest" (basal area, \% canopy cover, LWD, \% fine woody debris), (13) "understory vertical structure," (14) "vegetation" (\% canopy cover, basal area, understory vertical structure, \% moss, \% herbaceous vegetation, \% fern, and \% grass), (15) "woody debris" (LWD, decay class, and \% fine woody debris), and (16) a global model containing all 15 variables.

Linear regressions were used to analyze models (Burnham and Anderson, 2002; SPSS, 2012). Because salamander relative abundance beneath coverboard arrays was not significantly different

\footnotetext{
${ }^{3}$ Any use of trade, firm, or product names is for descriptive purposes only and does not imply endorsement by the U.S. Government.
} 
among years for mountain dusky salamanders, slimy salamanders, or eastern red-backed salamanders $(t=0.569, d f=142, P=0.570$; $t=-0.849, \quad d f=142, \quad P=0.397 ; \quad t=-0.051, \quad d f=142, \quad P=0.959$, respectively), we combined years to model habitat relationships. Prior to model selection, we examined residuals, measures of fit, classification tables, and histograms of expected probabilities for the global model to confirm goodness of fit (Burnham and Anderson, 2002). Akaike's Information Criterion corrected for small sample size was used for model selection because the number of coverboard arrays sampled ( $n=72$ ) was small relative to the number of parameters $(K)$ included in most models (i.e., $n / K<40)\left(\mathrm{AIC}_{c}\right.$; Hurvich and Pearson, 1989; Burnham and Anderson, 2002). We drew primary inference from models within 2 units of $\mathrm{AIC}_{c m i n}$ (i.e., substantial empirical support), although models within 4 units were also considered to have limited support. Parameter estimates, standard errors, and fit for models with substantial and limited empirical support were also reported.

We tested the effects of a shelterwood harvest after application of two consecutive prescribed fires on woodland salamander relative abundance using a one-way repeated measures ANOVA that used count data for individual salamander species by plot within harvested and unharvested sites. Control, shelterwood-burn, and fenced shelterwood-burn were levels of the treatment main effect. Because salamander surface activity differs among species, month sampled was used as a repeated measure to account for temporal variation and to reduce sampling bias within the study area (Bailey et al., 2004).

Fisher's Exact tests were used to determine if the ratio of juveniles to adults for each salamander species was equally dispersed among treatment types. Salamander age-class structure ratios of shelterwood-burn and fenced shelterwood-burn plots were compared to those in control treatments with statistical significance set at $\alpha \leqslant 0.025$ for these multiple comparisons. The Sorensen coefficient (Sorensen, 1948) was calculated to evaluate whether the salamander community was similar within sites before and after shelterwood harvest (Ford et al., 2010). Values ranged from 0 (no salamander species in common) to 1.0 (identical salamander species) within a treatment between studies.

\section{Results}

We captured a total of 129 salamanders under coverboard arrays within the Canoe Run watershed in 2011 and 2012. Species captured included 49 eastern red-backed salamanders, 40 slimy salamanders, 31 mountain dusky salamanders, 7 northern twolined salamanders (Eurycea bislineata), and 2 eastern newts (Notophthalmus viridescens). Mountain dusky salamanders, slimy salamanders, and eastern red-backed salamanders had sufficient captures for statistical analyses.

Several habitat characteristics varied significantly among control, shelterwood-burn, and fenced shelterwood-burn plots (Table 1). Large woody debris and percent understory vertical structure were significantly greater in shelterwood-burn and fenced shelterwood-burn plots than controls. Control plots had significantly greater canopy cover and bare ground than shelterwoodburn or fenced shelterwood-burn plots. Leaf litter depth was significantly greater in controls than shelterwood-burn plots. Shelterwood-burn plots had significantly more fine woody debris than control plots. Other habitat variables did not differ significantly among treatments (Table 1 ).

The best-approximating model explaining mountain dusky salamander relative abundance was the single variable "canopy cover" (Table 2). Mountain dusky salamander abundance was positively related to greater canopy cover (Table 3). The second-best model, "timber harvest," received only limited support $\left(\Delta \mathrm{AIC}_{c}=3.25, w_{i}<0.15\right.$; Table 2$)$. Weight of evidence for the "canopy cover" model was 5 times greater than that of the second-best model "timber harvest," indicating relatively little uncertainty in selection of the best model explaining mountain dusky salamander abundance (Burnham and Anderson, 2002). The remaining 13 models received little or no empirical support.

"Ground cover" was the best-approximating model explaining slimy salamander relative abundance (Table 2). Slimy salamander abundance was positively associated with greater percent cover of moss, fern, and grass, but negatively related to increases in herbaceous vegetation, leaf litter, and fine woody debris (Table 3). In addition, the second-best model, "vegetation," also received strong empirical support $\left(\Delta \mathrm{AIC}_{c}<2\right.$; Table 2$)$. The "vegetation" model indicated that slimy salamander abundance was positively associated with canopy cover, basal area, understory vertical structure, moss, fern, and grass, but negatively related to increased percent cover of herbaceous vegetation (Table 3). Weight of evidence for the "ground cover" model was 2.3 times greater than the "vegetation" model, indicating some uncertainty in selection of the best model (Burnham and Anderson, 2002). However, evidence for an influence of vegetative ground cover (e.g., moss, fern, grass, herbaceous vegetation) on slimy salamander abundance was strong because the sum of Akaike weights for the top best-supported models containing these variables was 0.85 (Table 2 ). The remaining 13 models received little or no empirical support for explaining slimy salamander abundance.

The single variable "leaf litter" was the best-approximating model explaining eastern red-backed salamander relative abundance (Table 2). Eastern red-backed salamander abundance increased with a greater percent cover of leaf litter (Table 3 ). The second-best model, "cover objects," also received strong empirical support $\left(\Delta \mathrm{AIC}_{c}<2\right.$; Table 2$)$. The "cover objects" model indicated that eastern red-backed salamander abundance was associated with greater percent cover of fine woody debris and leaf litter, but negatively related to large woody debris (Table 3). Weight of evidence for the "leaf litter" model was only 1.1 times greater than the "cover objects" model, indicating considerable uncertainty in selection of the best candidate model (Burnham and Anderson, 2002). However, evidence for the influence of leaf litter on eastern red-backed salamander abundance was evident because the sum of Akaike weights for the two best-supported models containing this variable was 0.65 (Table 2). The "decay class," “air temperature," "ground cover," and "landscape" models received limited support $\left(\Delta \mathrm{AIC}_{c}=2.69-3.35, w_{i}>0.06\right.$; Table 2$)$, and the remaining 9 models received little or no empirical support.

Mean relative abundance of captured mountain dusky salamanders, slimy salamanders, and eastern red-backed salamanders varied among treatments (Table 4). There was a significant treatment effect on mountain dusky salamander relative abundance but not for slimy salamanders or eastern red-backed salamanders (Table 5). A Tukey's post-hoc test indicated that control plots had significantly more mountain dusky salamanders than shelterwood-burn and fenced shelterwood-burn plots.

When analyzed separately, the ratios of juvenile to adult mountain dusky salamanders, slimy salamanders, and eastern redbacked salamanders did not differ among treatments (Table 6). Lastly, we compared the salamander assemblage observed during our study to previous research evaluating the effects of consecutive prescribed fires on woodland salamanders (Ford et al., 2010). The Sorensen Community Similarity Index values within control, shelterwood-burn, and fenced shelterwood-burn plots were 0.89 , 0.80 , and 0.73 , respectively.

\section{Discussion}

Habitat alterations resulting from timber harvest or prescribed fire are thought to negatively impact temperature- and 
Table 1

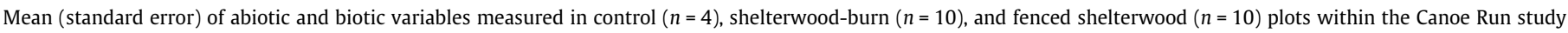

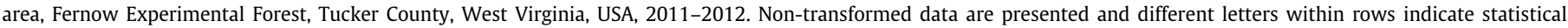
differences among treatments $(P \leqslant 0.05)$.

\begin{tabular}{|c|c|c|c|c|c|}
\hline Variable & Control & Shelterwood-burn & Fenced shelterwood-burn & $F$ & $P$ \\
\hline Slope $(\%)^{a}$ & $9.50(1.90)$ & $11.20(1.64)$ & $11.93(1.29)$ & 0.41 & 0.67 \\
\hline Elevation (m) & $681.36(47.30)$ & $709.22(21.26)$ & $708.15(23.05)$ & 0.23 & 0.80 \\
\hline Aspect (linear) & $258.33(29.27)$ & $254.33(10.36)$ & $239.67(17.15)$ & 0.34 & 0.72 \\
\hline Distance to stream (m) & $85.22(29.82)$ & $84.43(17.35)$ & $64.22(15.51)$ & 0.51 & 0.61 \\
\hline Basal area $\left(\mathrm{m}^{2}\right)$ & $0.48(0.05)$ & $0.18(0.04)$ & $0.24(0.05)$ & 1.77 & 0.20 \\
\hline Large woody debris $\left(\mathrm{m}^{2}\right)$ & $1.18(0.13) \mathrm{A}$ & $2.13(0.31) \mathrm{B}$ & $2.82(0.34) \mathrm{B}$ & 5.57 & 0.01 \\
\hline Decay class $(1-5)$ & $3.52(0.35)$ & $3.15(0.05)$ & $3.25(0.07)$ & 3.16 & 0.06 \\
\hline Canopy cover (\%) & $96.32(0.15) \mathrm{A}$ & 69.88 (2.29) B & $66.53(1.00) \mathrm{B}$ & 50.08 & $<0.01$ \\
\hline Understory vertical structure (\%) & $12.08(3.94) \mathrm{A}$ & $61.50(5.78) \mathrm{B}$ & $74.06(4.28) \mathrm{B}$ & 24.12 & $<0.01$ \\
\hline Moss (\%) & $1.77(1.11)$ & $1.54(0.67)$ & $1.21(0.57)$ & 0.06 & 0.95 \\
\hline Herbaceous vegetation (\%) & $7.08(1.35)$ & $5.04(0.34)$ & $4.83(0.58)$ & 1.07 & 0.36 \\
\hline Fern $(\%)$ & $1.98(1.15)$ & $2.88(0.93)$ & $0.71(0.22)$ & 2.19 & 0.14 \\
\hline Grass (\%) & $0.10(0.10)$ & $1.46(0.65)$ & $0.42(0.19)$ & 2.22 & 0.13 \\
\hline Leaf $(\%)$ & $59.33(5.82)$ & $48.13(4.89)$ & $57.42(4.08)$ & 1.49 & 0.25 \\
\hline $\operatorname{Rock}(\%)^{a}$ & $3.75(2.00)$ & $9.13(3.72)$ & $6.46(3.59)$ & 0.27 & 0.77 \\
\hline Fine woody debris (\%) & $14.90(1.87) \mathrm{A}$ & 30.17 (3.56) B & $27.58(3.21) \mathrm{AB}$ & 3.40 & 0.05 \\
\hline Bare $(\%)^{a}$ & $11.04(4.51) \mathrm{A}$ & $1.67(0.58) \mathrm{B}$ & 1.38 (0.92) B & 10.91 & $<0.01$ \\
\hline Leaf litter depth $(\mathrm{mm})^{\mathrm{a}}$ & $1.41(0.46) \mathrm{A}$ & $0.56(0.08) \mathrm{B}$ & $0.80(0.16) \mathrm{AB}$ & 3.80 & 0.04 \\
\hline Air temperature $\left({ }^{\circ} \mathrm{C}\right)$ & $22.91(0.60)$ & $23.37(1.03)$ & $24.25(0.78)$ & 0.45 & 0.65 \\
\hline Humidity $(\%)^{\mathrm{a}}$ & $80.54(3.38)$ & $81.48(2.26)$ & $80.36(2.62)$ & 0.06 & 0.94 \\
\hline Soil temperature $\left({ }^{\circ} \mathrm{C}\right)^{\mathrm{a}}$ & $19.75(0.35)$ & $20.79(0.64)$ & $20.50(0.32)$ & 0.61 & 0.55 \\
\hline
\end{tabular}

a Variables were not used in regression analyses due to intercorrelation $\left(r_{s} \geqslant 0.65\right)$.

Table 2

Best-approximating models $\left(\Delta \mathrm{AIC}_{c}\right)$ explaining the influence of abiotic and biotic habitat variables on mountain dusky salamander, slimy salamander, and eastern redbacked salamander relative abundance in the Canoe Run study area, Fernow Experimental Forest, Tucker County, West Virginia, USA, 2011-2012.

\begin{tabular}{|c|c|c|c|c|}
\hline Model $^{\mathrm{a}}$ & RSS & $K^{\mathrm{b}}$ & $\Delta \mathrm{AIC}_{c}{ }^{\mathrm{c}}$ & $w_{i}^{\mathrm{d}}$ \\
\hline \multicolumn{5}{|c|}{ Mountain dusky salamander } \\
\hline Canopy cover $^{A}$ & 18.49 & 3 & 0.00 & 0.75 \\
\hline Timber harvest & 17.57 & 6 & 3.25 & 0.15 \\
\hline \multicolumn{5}{|l|}{ Slimy salamander } \\
\hline Ground cover $^{\mathrm{A}}$ & 17.26 & 8 & 0.00 & 0.59 \\
\hline Vegetation $^{\mathrm{A}}$ & 17.02 & 9 & 1.64 & 0.26 \\
\hline \multicolumn{5}{|c|}{ Eastern red-backed salamander } \\
\hline Leaf litter ${ }^{A}$ & 28.26 & 3 & 0.00 & 0.33 \\
\hline Cover objects $^{\mathrm{A}}$ & 26.56 & 5 & 0.10 & 0.32 \\
\hline Decay class & 29.34 & 3 & 2.69 & 0.09 \\
\hline Air temperature & 29.48 & 3 & 3.05 & 0.07 \\
\hline Ground cover & 25.06 & 8 & 3.27 & 0.07 \\
\hline Landscape & 28.70 & 4 & 3.35 & 0.06 \\
\hline
\end{tabular}

a See text for model variable description.

b Number of estimable parameters in approximating model.

c Difference in value between $\mathrm{AIC}_{c}$ of the current vs the best approximating model $\left(\mathrm{AIC}_{\mathrm{cmin}}\right)$.

d Akaike weight. Probability that the current model $\left(w_{i}\right)$ is the best approximating model among those considered.

${ }^{\mathrm{A}}$ Model with high empirical support $\left(\Delta \mathrm{AIC}_{c} \leqslant 2\right)$.

moisture-dependent woodland salamanders associated with mature and late-successional habitats (deMaynadier and Hunter, 1995; Pilliod et al., 2003; Russell et al., 2004; Renken, 2006; Moorman et al., 2011). These forest management practices alter site conditions (e.g., increase forest floor temperatures and decrease soil moisture), potentially making habitat conditions less suitable for woodland salamanders and causing a reduction in populations (deMaynadier and Hunter, 1995; Moorman et al., 2011). However, the results of our study and previous research indicate that woodland salamanders do remain in forests subjected to combined shelterwood and burning management regimes (Greenberg and Waldrop, 2008; Ford et al., 2010). Specifically, our results indicate that species responded differently to changes in habitat characteristics within post-shelterwood-burn sites.
Among species captured, mountain dusky salamanders appeared most sensitive to the effects of shelterwood harvesting, similar to salamander responses following shelterwood harvests in the Ozarks of Missouri (O'Donnell et al., 2015). The bestapproximating model explaining mountain dusky salamander relative abundance was the single-variable model "canopy cover." This species was strongly associated with control plots, which contained significantly greater amounts of overhead canopy than shelterwood harvest sites. Also at the Fernow Experimental Forest, Moseley et al. (2008) observed that the best-approximating model explaining the abundance of stream-dwelling Desmognathus spp. was overstory volume/ha removed over a 50-year period, with salamander abundance decreasing with increased timber removal. Although mountain dusky salamanders are known to disperse from streams into upland forests as much as $61 \mathrm{~m}$ (Hairston, 1949), this species is thought to require relatively undisturbed, mesic habitats (Petranka, 1998), reflecting potential physical constraints for microhabitats more indicative of streamside areas (Grover and Wilbur, 2002). Therefore, this species' preference for mesic areas appears to make it more sensitive to shelterwood harvest, at least in the short-term, when compared to other woodland salamander species.

In contrast, slimy salamanders were more strongly linked with other aspects of vegetative structure. The two best-approximating models explaining slimy salamander relative abundance were "ground cover" and "vegetation." With the exception of canopy cover, understory vertical structure, and fine woody debris, variables within these models were not significantly different among treatments. Also, the abundance of slimy salamanders did not differ among treatments, indicating that conditions within treatment sites were suitable for this species. Likewise, slimy salamander abundance was similar between clearcut and mature forest stands, suggesting that this species may be more resilient to disturbances associated with various forest management practices (Petranka et al., 1993). Understory vegetation is important for woodland salamander foraging and providing shade, especially to mitigate effects of canopy removal (Pough et al., 1987; Homyack and Haas, 2009). In fact, the composition or type of understory cover by itself may not be as important to woodland salamanders as the cool, moist conditions maintained underneath (Heatwole, 1962). Within our 
Table 3

Parameter estimates $(B)$ and standard errors (SE) from the best-approximating models explaining the influence of habitat variables on mountain dusky salamander, slimy salamander, and eastern red-backed salamander relative abundance in the Canoe Run study area, Fernow Experimental Forest, Tucker County, WV, USA, 2011-2012.

\begin{tabular}{|c|c|c|c|}
\hline Model & $B$ & $S E$ & $R^{2}$ \\
\hline \multicolumn{4}{|l|}{ Mountain dusky salamander } \\
\hline Canopy cover ${ }^{\mathrm{a}}$ & & & 0.29 \\
\hline Intercept & -1.53 & 0.34 & \\
\hline Canopy cover & 0.03 & 0.01 & \\
\hline Timber harvest & & & 0.32 \\
\hline Intercept & -1.08 & 0.44 & \\
\hline Basal area & 0.26 & 0.24 & \\
\hline Canopy cover & -0.01 & 0.09 & \\
\hline Large woody debris & 0.02 & 0.01 & \\
\hline Fine woody debris & -0.01 & 0.01 & \\
\hline \multicolumn{4}{|l|}{ Slimy salamander } \\
\hline Ground cover ${ }^{\mathrm{a}}$ & & & 0.28 \\
\hline Intercept & 1.50 & 0.58 & \\
\hline Moss & 0.03 & 0.02 & \\
\hline Herbaceous vegetation & -0.25 & 0.11 & \\
\hline Fern & 0.02 & 0.01 & \\
\hline Grass & 0.02 & 0.02 & \\
\hline Leaf litter & -0.01 & 0.01 & \\
\hline Fine woody debris & -0.02 & 0.01 & \\
\hline Vegetation $^{\mathrm{a}}$ & & & 0.29 \\
\hline Intercept & -0.54 & 0.71 & \\
\hline Canopy cover & 0.01 & 0.01 & \\
\hline Basal area & 0.33 & 0.25 & \\
\hline Understory obscurity & 0.01 & 0.01 & \\
\hline Moss & 0.04 & 0.01 & \\
\hline Herbaceous vegetation & -0.22 & 0.11 & \\
\hline Fern & 0.03 & 0.01 & \\
\hline Grass & 0.04 & 0.02 & \\
\hline \multicolumn{4}{|c|}{ Eastern red-backed salamander } \\
\hline Leaf litter ${ }^{\mathrm{a}}$ & & & 0.10 \\
\hline Intercept & -0.21 & 0.25 & \\
\hline Leaf litter & 0.01 & 0.01 & \\
\hline Cover objects $^{\mathrm{a}}$ & & & 0.16 \\
\hline Intercept & -0.86 & 0.43 & \\
\hline Large woody debris & -0.10 & 0.10 & \\
\hline Fine woody debris & 0.02 & 0.01 & \\
\hline Leaf litter & 0.01 & 0.01 & \\
\hline Decay class & & & 0.01 \\
\hline Intercept & 0.01 & 0.49 & \\
\hline Decay class & 0.14 & 0.15 & \\
\hline Air temperature & & & 0.07 \\
\hline Intercept & -1.01 & 0.68 & \\
\hline Air temperature & 0.06 & 0.03 & \\
\hline Ground cover & & & 0.21 \\
\hline Intercept & 0.09 & 0.69 & \\
\hline Moss & 0.00 & 0.02 & \\
\hline Herbaceous vegetation & -0.29 & 0.13 & \\
\hline Fern & 0.00 & 0.01 & \\
\hline Grass & 0.00 & 0.02 & \\
\hline Leaf litter & 0.02 & 0.01 & \\
\hline Fine woody debris & 0.01 & 0.01 & \\
\hline Landscape & & & 0.09 \\
\hline Intercept & -0.97 & 0.80 & \\
\hline Elevation & 0.00 & 0.00 & \\
\hline Aspect & -0.17 & 0.14 & \\
\hline
\end{tabular}

${ }^{\text {a }}$ Model with high empirical support $\left(\Delta \mathrm{AIC}_{c} \leqslant 2\right)$.

study, treatment plots exhibited significantly greater understory vertical structure as a consequence of the shelterwood-burn, which may have at least partially offset any potential effects of canopy reduction on slimy salamanders.

Eastern red-backed salamander relative abundance was best explained by the models "leaf litter" and "cover objects," indicating
Table 4

Mean relative abundance and standard error (SE) of woodland salamanders in control $(n=4)$, shelterwood-burn $(n=10)$, and fenced shelterwood-burn $(n=10)$ treatments by coverboard array within the Canoe Run study area, Fernow Experimental Forest Tucker County, West Virginia, USA, 2011-2012.

\begin{tabular}{|c|c|c|c|c|c|c|}
\hline \multirow[t]{2}{*}{ Treatment } & \multicolumn{2}{|c|}{$\begin{array}{l}\text { Mountain } \\
\text { dusky } \\
\text { salamander }\end{array}$} & \multicolumn{2}{|c|}{$\begin{array}{l}\text { Slimy } \\
\text { salamander }\end{array}$} & \multicolumn{2}{|c|}{$\begin{array}{l}\text { Eastern } \\
\text { red-backed } \\
\text { salamander }\end{array}$} \\
\hline & Mean & $S E$ & Mean & SE & Mean & $S E$ \\
\hline \multicolumn{7}{|l|}{2011} \\
\hline Control & 0.33 & 0.10 & 0.06 & 0.04 & 0.19 & 0.09 \\
\hline Shelterwood-burn & 0.01 & 0.01 & 0.10 & 0.03 & 0.08 & 0.04 \\
\hline Fenced shelterwood-burn & 0.03 & 0.02 & 0.07 & 0.03 & 0.11 & 0.04 \\
\hline \multicolumn{7}{|l|}{2012} \\
\hline Control & 0.36 & 0.11 & 0.25 & 0.09 & 0.19 & 0.09 \\
\hline Shelterwood-burn & 0.01 & 0.01 & 0.07 & 0.03 & 0.03 & 0.02 \\
\hline Fenced shelterwood-burn & 0.01 & 0.01 & 0.09 & 0.03 & 0.17 & 0.04 \\
\hline
\end{tabular}

Table 5

One-way repeated measures ANOVA of treatment effects (control $(n=4)$, shelterwood-burn $(n=10)$, and fenced shelterwood-burn $(n=10))$, accounting for month variability (May, July and August-September), for mountain dusky salamanders, slimy salamanders, and eastern red-backed salamanders relative abundance in the Canoe Run study area, Fernow Experimental Forest, Tucker County, West Virginia, USA, 2011-2012.

\begin{tabular}{llrlll}
\hline Species & Effect & df & MS & \multicolumn{1}{c}{$F$} & $P$ \\
\hline Mountain dusky salamander & Treatment & 2 & 6.99 & 23.37 & $<0.01$ \\
& Error & 21 & 0.30 & & \\
& Total & 23 & & & \\
Slimy salamander & Treatment & 2 & 0.49 & 1.84 & 0.18 \\
& Error & 21 & 0.27 & & \\
& Total & 23 & & & \\
Eastern red-backed salamander & Treatment & 2 & 0.77 & 1.35 & 0.28 \\
& Error & 21 & 0.57 & & \\
& Total & 23 & & &
\end{tabular}

\section{Table 6}

Fisher's Exact tests comparing mountain dusky salamander, slimy salamander, and eastern red-backed salamander age-class structure between control and shelterwood-harvested plots in the Canoe Run study area, Fernow Experimental Forest, Tucker County, West Virginia, USA, 2011-2012. Numbers of captures within each treatment type are separated by commas. Significance was set at $P \leqslant 0.025$ and $d f=1$ for all comparisons.

\begin{tabular}{|c|c|c|c|}
\hline Treatment comparison & Juveniles & Adults & $\begin{array}{l}\text { Fisher's Exact } \\
\text { test }(P)\end{array}$ \\
\hline \multicolumn{4}{|l|}{ Mountain dusky salamander } \\
\hline Control vs shelterwood-burn & 5,0 & 20,2 & 1.00 \\
\hline Control vs fenced shelterwood-burn & 5,2 & 20,2 & 0.24 \\
\hline \multicolumn{4}{|l|}{ Slimy salamander } \\
\hline Control vs shelterwood-burn & 9,13 & 2,1 & 0.57 \\
\hline Control vs fenced shelterwood-burn & 9,10 & 2,1 & 1.00 \\
\hline \multicolumn{4}{|l|}{ Eastern red-backed salamander } \\
\hline Control vs shelterwood-burn & 11,6 & 3,4 & 0.39 \\
\hline Control vs fenced shelterwood-burn & 11,20 & 3,5 & 1.00 \\
\hline
\end{tabular}

that this species was positively associated with an increase in leaf litter cover. Abundance of woodland salamanders has been positively correlated with deposition of leaf litter after silvicultural disturbances (Pough et al., 1987). However, in our study percent cover of leaf litter did not differ significantly among treatments. Fine woody debris was the only variable within the bestapproximating models for eastern red-backed salamanders that was significantly different among treatments. Nevertheless, the impacts of shelterwood harvest on eastern red-backed salamanders appear negligible as fine woody debris was greater in 
shelterwood-burn plots and abundance did not differ among treatments. Therefore, within treatment sites, retained and/or the continual formation of leaf litter and woody debris may have been adequate to counteract any deleterious effects of significant canopy reduction on this species by providing sufficiently cool, moist microhabitat conditions.

Although the most important explanatory habitat variables differed among mountain dusky salamanders, slimy salamanders, and eastern red-backed salamanders, abundance for all species appeared to relate to habitat characteristics that influence forest floor moisture and temperature. All three species belong to Family Plethodontidae, but there are marked life history differences between Desmognathus spp. and Plethodon spp. Mountain dusky salamanders and other Desmognathus spp. are associated with streams and riparian habitats to a much greater extent than species in the genus Plethodon. Relative to Desmognathus spp., slimy salamanders and eastern red-backed salamanders appear less sensitive to habitat alterations, including timber harvest, than previously thought (Petranka et al., 1993; Hocking et al., 2013). For example, large numbers of eastern red-backed salamanders were found in silvo-pastures and hay meadows in West Virginia that contained little to no overstory cover (Riedel et al., 2008). Simple presence or retention of dense, moisture-trapping herbaceous vegetation probably enables this species to occupy non-forested habitats. Similarly within our study, the retention of leaf litter, fine woody debris, and other ground cover after shelterwood harvesting may explain the apparent insensitivity of eastern red-backed salamanders and slimy salamanders to partial removal of the forest canopy. Also, compared to mountain dusky salamanders, the larger body size of slimy salamanders, and even eastern red-backed salamanders, may enable these species to more readily occupy shelterwood-harvested and other disturbed sites. Petranka et al. (1993) found clearcuts contained significantly fewer individuals of several species of Plethodon spp. and Desmognathus spp. than mature forests, but slimy salamander abundance was similar between cut and uncut stands. Larger-bodied salamanders lose water at a slower rate (Spotila and Berman, 1976; Feder, 1983), potentially allowing these individuals to survive drier conditions when compared to smaller-bodied individuals.

The shelterwood harvest that we evaluated was the next step in a management regime that started with the application of two prescribed burns in 2002-2003 and 2005 (Ford et al., 2010). Because of large differences in detection probabilities, partly related to differences in mark-recapture methods, we were unable to directly incorporate data from Ford et al. (2010) into our analyses. In addition, Ford et al. (2010) separated treatments more finely to account for differences in slope position. Regardless, captures of each species appeared noticeably reduced in treatment plots when compared to previous data collected from the same plots (Ford et al. 2010). Therefore, it is possible that the cumulative effects of burning and harvesting may have reduced abundance of woodland salamanders to a greater degree than either treatment separately in the short-term.

However, noticeable differences in mean captures between our study and research initiated 10 years previously on the same plots (Ford et al., 2010) could be related to post-harvest changes in forest floor habitats that influenced coverboard use by salamanders rather than a negative effect of harvesting by itself. When leaf litter, woody debris, or other natural cover is reduced or removed, surface-active woodland salamanders may instead be found under artificial coverboards more frequently (Ford et al., 2010; O'Donnell et al., 2015) or exclusively (Riedel et al., 2008). In contrast, when natural surface cover is abundant, salamanders may be less attracted to artificial cover, and therefore, under represent actual numbers of surface active individuals (Marsh and Goicochea, 2003; Bailey et al., 2004). In our study shelterwood harvest likely increased the amount of large woody debris, lessening salamander dependence on coverboards compared to previous conditions of reduced natural cover immediately following prescribed fire on the same sites (Ford et al., 2010).

In addition to relative abundance, we evaluated whether ageclass structure of woodland salamanders was affected by the shelterwood-burn silvicultural treatment. If populations exhibit atypical age-class distributions, sex ratios, or physical condition (e.g., mass), density estimates may not accurately reflect habitat quality or population health (Ash et al., 2003; Riedel et al., 2012). Because of their larger surface area to volume ratios when compared to adults, juvenile salamanders are less able to remain hydrated in areas with reduced canopy cover and therefore more prone to desiccation-induced mortality (Hairston, 1987; Marsh and Goicochea, 2003). However, in contrast with some previous studies (e.g., Ash et al., 2003; Homyack and Haas, 2009; Riedel et al., 2012), we found no significant differences in the proportion of juvenile to adult mountain dusky salamanders, slimy salamanders, or eastern red-backed salamanders among treatments. Similarly, Ford et al. (2010) found differences in age-class structure were largely equivocal, suggesting that consecutive prescribed fires did not alter the adult to juvenile ratios.

Although woodland salamander abundance potentially declined with the cumulative effects of prescribed burning and shelterwood harvesting, salamander community composition was similar to that reported by Ford et al. (2010) prior to timber harvesting. Specifically, the existing woodland salamander assemblage, largely consisting of mountain dusky salamanders, slimy salamanders, and eastern red-backed salamanders, remained intact despite application of prescribed burning followed by shelterwood harvesting. Similarly, woodland salamanders, including slimy salamanders and eastern red-backed salamanders, were unaffected by shelterwood-burn treatments within oak-dominated forests of the Virginia Piedmont (Keyser et al., 2004). Overall, the post-shelterwood-burn salamander assemblage within our study area remained throughout 10 years of forest management.

\section{Conclusions}

The shelterwood-burn silvicultural system requires several stand entries for both prescribed fire and timber removal, taking 10 years or more to complete (Burns and Honkala, 1990). Therefore, this process has the potential to exert cumulative negative impacts on salamander communities (Moseley et al., 2008; Moorman et al., 2011; O'Donnell et al., 2015). Within our study area, the overall salamander assemblage appeared largely unaffected by multiple prescribed burns followed by shelterwood harvesting. However, our results indicate that some species, including mountain dusky salamanders, may experience at least temporary declines in abundance related to these treatments.

Temporary negative impacts of shelterwood-burn forest management to a few site-specific species, including mountain dusky salamanders, should not outweigh benefits to wildlife communities as a whole. Restoring oaks within Appalachian landscapes is important not only for ecological restoration purposes or commercial timber value but also because these trees serve as critical forage and cover for a variety of wildlife species (Brose et al., 1999; McWilliams et al., 2002). Furthermore, shelterwood-burn treatments are usually applied on a relatively small scale in the region enabling salamanders or other treatment-sensitive wildlife species to persist within the surrounding landscape until conditions within active management areas become more suitable over time.

Although our research fills an important gap in our understanding of salamander responses to the cumulative effects of forest 
management treatments, continued monitoring of woodland salamander responses to shelterwood treatments in conjunction with burn prescriptions, as well as other silvicultural practices, is suggested. A more complete understanding of woodland salamander responses to these prescriptions can provide forest managers with valuable information on how to conserve wildlife habitats while maintaining forest composition and structure within central Appalachian deciduous forests.

\section{Acknowledgments}

We thank Richard Hovatter, Donald Lowther, and Melissa Thomas-Van Gundy for their advice and assistance during the project. We also thank Kurt Moseley, Jessica Orlando, William Fields, Blake Hossack, and one anonymous reviewer for reviewing an earlier draft of this manuscript. Our research was supported financially and logistically by the USDA Forest Service Northern Research Station and the University of Wisconsin-Stevens Point through participating agreement \#11-JV-11242301-044. All animals were handled according to a West Virginia Division of Natural Resources Scientific Collecting Permit and the University of Wisconsin-Stevens Point Institutional Animal Care and Use Committee Protocol \#20131108.

\section{References}

Abrams, M.D., 1992. Fire and the development of oak forests. Bioscience 42, $346-$ 353 .

Adams, M.B., Loughry, L., Plaugher, L., 2008. Experimental forests and ranges of the USDA Forest Service. General Technical Report NE-321. USDA Forest Service, Northeastern Research Station, Newton Square, PA, pp. 44-45.

Ash, A.N., 1988. Disappearance of salamanders from clearcut plots. J. Elisha Mitchell Sci. Soc. 104, 116-122.

Ash, A.N., Bruce, R.C., Castanet, J., Francillon-Vieillot, H., 2003. Population parameters of Plethodon metcalfi on a 10-year-old clearcut and in nearby forest in the southern Blue Ridge Mountains. J. Herpetology 37, 445-452.

Bailey, L.L., Simons, T.R., Pollock, K.H., 2004. Estimating detection probability parameters for Plethodon salamanders using the robust capture-recapture design. J. Wildlife Manage. 68, 1-13.

Bartman, C.E., Parker, K.C., Laerm, J., McCay, T.S., 2001. Short-term response of Jordan's salamander to a shelterwood timber harvest in western North Carolina. Phys. Geogr. 22, 154-166.

Braun, E.L., 1950. Deciduous Forests of Eastern North America. Blakiston Co., Philadelphia, Pennsylvania, USA.

Brose, P.H., Van Lear, D.H., 1998. Responses of hardwood advance regeneration to seasonal prescribed fires in oak-dominated shelterwood stands. Can. J. For. Res. 28, 331-339.

Brose, P., Van Lear, D., Cooper, R., 1999. Using shelterwood harvests and prescribed fire to regenerate oak stands on productive upland sites. For. Ecol. Manage. 113, $125-141$.

Brose, P., Schuler, T., Van Lear, D., Berst, J., 2001. Bringing fire back: the changing regimes of the Appalachian mixed-oak forests. J. For. 99, 30-35.

Burnham, K.P., Anderson, D.R., 2002. Model Selection and Multimodel Inference: A Practical Information-theoretic Approach. Springer, New York, New York, USA.

Burns, R.M., Honkala, B.H., 1990. Silvics of North America. Volume 2 Hardwoods. USDA Handbook 654. Washington, DC, USA.

Daubenmire, R., 1959. A canopy-coverage method of vegetational analysis. Northwest Sci. 33, 43-64.

DeGraaf, R.M., Yamasaki, M., 1992. A nondestructive technique to monitor the relative abundance of terrestrial salamanders. Wildl. Soc. Bull. 20, 260-264.

deMaynadier, P.G., Hunter Jr., M.L., 1995. The relationship between forest management and amphibian ecology: a review of the North American literature. Environ. Rev. 3, 230-261.

Duellman, W.E., Trueb, L., 1986. Biology of Amphibians. McGraw-Hill, New York, New York, USA.

ESRI Inc., 2012. ArcGIS 10.1. Redlands, CA, USA.

Feder, M.E., 1983. Integrating the ecology and physiology of plethodontid salamanders. Herpetologica 39, 291-310.

Floyd, T.M., Russell, K.R., Moorman, C.E., Van Lear, D.H., Guynn Jr., D.C., Lanham, J.D., 2002. Effects of prescribed fire on herpetofauna within hardwood forests of the upper Piedmont of South Carolina: a preliminary analysis. In: Outcalt, K.W. (Ed.), Proceedings of the Eleventh Biennial Southern Silvicultural Research Conference. General Technical Report SRS-48. USDA Forest Service, Southern Research Station, Asheville, NC, pp. 123-127.

Ford, W.M., Menzel, M.A., McGill, D.W., Laerm, J., McCay, T.S., 1999. Effects of a community restoration fire on small mammals and herpetofauna in the southern Appalachians. For. Ecol. Manage. 114, 233-243.
Ford, W.M., Menzel, M.A., McCay, T.S., Gassett, J.W., Laerm, J., 2000. Woodland salamander and small mammal responses to alternative silvicultural practices in the southern Appalachians of North Carolina. Proc. Ann. Conf. Southeast Assoc. Fish Wildlife Agencies 54, 241-250.

Ford, W.M., Menzel, M.A., Odom, R.H., 2002. Elevation, aspect, and cove size effects on southern Appalachian salamanders. Southeast. Nat. 1, 315-324.

Ford, W.M., Rodrigue, J.L., Rowan, E.L., Castleberry, S.B., Schuler, T.M., 2010 Woodland salamander responses to two prescribed fires in the central Appalachians. For. Ecol. Manage. 260, 1003-1009.

Green, N.B., Pauley, T.K., 1987. Amphibians and Reptiles in West Virginia. University of Pittsburgh Press, Pittsburgh, Pennsylvania, USA.

Greenberg, C.H., Waldrop, T.A., 2008. Short-term response of reptiles and amphibians to prescribed fore and mechanical fuel reduction in a southern Appalachian upland hardwood forest. For. Ecol. Manage. 255, 2883-2893.

Grover, M.C., Wilbur, H.M., 2002. Ecology of ecotones: interactions between salamanders on a complex environmental gradient. Ecology 83, 2112-2123.

Hairston, N.G., 1949. The local distribution and ecology of the plethodontid salamanders of the southern Appalachians. Ecol. Monogr. 19, 47-73.

Hairston, N.G., 1987. Community Ecology and Salamander Guilds. Cambridge University Press, Cambridge, United Kingdom.

Harpole, D.N., Haas, C.A., 1999. Effects of seven silvicultural treatments on terrestrial salamanders. For. Ecol. Manage. 114, 349-356.

Heatwole, H., 1962. Environmental factors influencing local distribution and activity of the salamander, Plethodon cinereus. Ecology 43, 460-472.

Hero, J.M., 1989. A simple code for toe clipping anurans. Herpetological Rev. 20, 6667.

Hocking, D.J., Connette, G.M., Conner, C.A., Scheffers, B.R., Pittman, S.E., Peterman, W.E., Semlitsch, R.D., 2013. Effects of experimental forest management on a terrestrial, woodland salamander in Missouri. For. Ecol. Manage. 287, 32-39.

Homyack, J.A., Haas, C.A., 2009. Long-term effects of experimental forest harvesting on abundance and reproductive demography of terrestrial salamanders. Biol Conservation 142, 110-121.

Huggins, R.M., 1989. On the statistical analysis of capture experiments. Biometrika 76, 133-140.

Hurvich, C., Pearson, S.M., 1989. Regression and time series model selection in small samples. Biometrika 76, 297-307.

Keyser, P.D., Sausville, D.J., Ford, W.M., Schwab, D.J., Brose, P.H., 2004. Prescribed fire impacts to amphibians and reptiles in shelterwood-harvested oak-dominated forests. Virginia J. Sci. 55, 159-167.

Kirkland, G.L., Snoddy, H.W., Amsler, T.L., 1996. Impact of fire on small mammals and amphibians in a central Appalachian deciduous forest. Am. Midland Nat. 135, 253-260.

Knapp, S.M., Haas, C.A., Harpole, D.N., Kirkpartrick, R.L., 2003. Initial effects of clearcutting and alternative silvicultural practices on terrestrial salamander abundance. Conservation Biol. 17, 752-762.

Kuehl, R.O., 2000. Design of Experiments: Statistical Principles of Research Design and Analysis, second ed. Duxbury Press, Pacific Grove, California, USA.

Lemmon, P.E., 1956. A spherical densitometer for estimating forest overstory density. For. Sci. 2, 314-320.

Marsh, D.M., Goicochea, M.A., 2003. Monitoring terrestrial salamanders: biases caused by intense sampling and choice of cover objects. J. Herpetology 37, 460466.

Maser, C., Anderson, R.G., Cromack Jr., K., Williams, J.T., Martin, R.E, 1979. Dead and down woody material. In: Thomas, J.W. (Ed.), Wildlife Habitats in Managed Forests: The Blue Mountains of Oregon and Washington. Agriculture Handbook 553. USDA Forest Service, Washington, D.C., pp. 78-95.

Matthews, C.E., Moorman, C.E., Greenberg, C.H., Waldrop, T.A., 2010. Response of reptiles and amphibians to repeated fuel reduction treatments. J. Wildlife Manage. 74, 1301-1310.

McWilliams, W.H., O’Brien, R.A., Reese, G.C., Waddell, K.L., 2002. Distribution and abundance of oaks in North America. In: McShea, W.J., Healy, W.M. (Eds.), Oak Forest Ecosystems: Ecology and Management for Wildlife. The Johns Hopkins University Press, Baltimore, Maryland, USA, pp. 13-33.

Moorman, C.E., Russell, K.R., Greenberg, C.H., 2011. Reptile and amphibian response to hardwood forest management and early successional habitat. In: Greenberg, C.H., Collins, B., Thompson, F.R. (Eds.), Ecology and Management of Early Successional Habitats in the Central Hardwood Region, USA. Springer, The Netherlands, pp. 191-208.

Moseley, K.R., Ford, W.M., Edwards, J.W., Schuler, T.M., 2008. Long-term partial cutting impacts on Desmognathus salamander abundance in West Virginia headwater streams. For. Ecol. Manage. 254, 300-307.

Nowacki, G.J., Abrams, M.D., 2008. The demise of fire and "mesophication" of forests in the eastern United States. BioScience 58, 123-138.

O'Donnell, K.M., Thompson, F.R., Semlitsch, R.D., 2015. Prescribed fire and timber harvest effects on terrestrial salamander abundance, detectability and habitat use. J. Wildlife Manage. 79, 766-775.

Petranka, J.W., 1998. Salamanders of the United States and Canada. Smithsonian Institution Press, Washington, D.C., USA.

Petranka, J.W., Eldridge, M.E., Haley, K.E., 1993. Effects of timber harvesting on southern Appalachian salamanders. Conservation Biol. 7, 363-370.

Pilliod, D.S., Bury, R.B., Hyde, E.J., Pearl, C.A., Corn, P.S., 2003. Fire and amphibians in North America. For. Ecol. Manage. 178, 163-181.

Pough, F.H., Smith, E.M., Rhodes, D.H., Collazo, A., 1987. The abundance of salamanders in forest stands with different histories of disturbance. For. Ecol Manage. 20, 1-9. 
Raybuck, A.L., Moorman, C.E., Fritts, S.R., Greenberg, C.H., Deperno, C.S., Simon, D.M. Warburton, G.S., 2015. Do silvicultural practices to restore oaks affect salamanders in the short term? Wildlife Biol. 21, 186-194.

Renken, R.B., 2006. Does fire affect amphibians and reptiles in eastern U.S. oak forests? In: Dickson, M.B. (Ed.), Fire in Eastern Oak Forests: Delivering Science to Land Managers, Proceedings of a Conference. General Technical Report NRSP-1. USDA Forest Service, Northeastern Research Station, Newton Square, PA, pp. 158-166.

Riddle, J.D., Moorman, C.E., Pollock, K.H., 2008. The importance of habitat shape and landscape context to northern bobwhite populations. J. Wildlife Manage. 72 1437-1442.

Riedel, B.L., Russell, K.R., Ford, W.M., O'Neill, K.P. Godwin, H.W., 2008. Habitat relationships of eastern red-backed salamanders (Plethodon cinereus) in Appalachian agroforestry and grazing systems. Agric. Ecosyst. Environ. 124, 229-236.

Riedel, B.L., Russell, K.R., Ford, W.M., 2012. Physical condition, sex, and age-class of eastern red-backed salamanders (Plethodon cinereus) in forested and open habitats of West Virginia. Int. J. Zool. 2012, 1-8.

Robel, R.J. Briggs, J.N. Dayton, A.D., Hulbert, L.C., 1970. Relationships between visual obstruction measurements and weight of grassland vegetation. J. Range Manage. 23, 295-297.

Russell, K.R., Van Lear, D.H., Guynn Jr., D.C., 1999. Prescribed fire effects on herpetofauna: review and management implications. Wildlife Soc. Bull. 27, 374-384.

Russell, K.R., Wigley, T.B., Baughman, W.M., Hanlin, H.G., Ford, W.M., 2004 Responses of southeastern amphibians and reptiles to forest management: a review. In: Rauscher, H.M., Johnsen, K. (Eds.), Southern Forest Science: Past, Present, and Future. General Technical Report SRS-75, USDA Forest Service, Southern Research Station, Asheville, NC, pp. 319-334.

Sattler, P., Reichenbach, N., 1998. The effects of timbering on Plethodon hubrichti: short-term effects. J. Herpetology 32, 399-404.

Schuler, T.M., Miller, G.W., 1995. Shelterwood treatments fail to establish oak reproduction on mesic forest sites in West Virginia. In: Gottschalk, K.W. Fosbroke, S.L.C. (Eds.), Proceedings of the 10th Central Hardwood Conference.
General Technical Report NE-197. USDA Forest Service, Northeastern Research Station, Newton Square, PA, pp. 375-388.

Schuler, T.M., Thomas-Van Gundy, M., Adams, M.B., Ford, W.M., 2010. Seed bank response to prescribed fire in the central Appalachians. General Technical Report NRS-9. USDA Forest Service, Northeastern Research Station, Newton Square, PA, p. 9.

Schuler, T.M., Thomas-Van Gundy, M., Adams, M.B., Ford, W.M., 2012. Analysis of two pre-shelterwood prescribed fires in a mesic mixed-oak forest in West Virginia. In: Miller, G.W., Schuler, T.M., Gottschalk, K.W., Brooks, J.R., Grushecky, S.T., Spong, B.D., Rentch, J.S. (Eds.), Proceedings of the 18th Central Hardwoods Forest Conference. General Technical Report NRS-P-117. USDA Forest Service, Northeastern Research Station, Newton Square, PA, pp. 430-446.

Sefidi, K., Mohadjer, M.R.M., 2010. Characteristics of coarse woody debris in successional stages of natural beech (Fagus orientalis) forests of Northern Iran. J. For. Sci. 56, 7-17.

Sorensen, T., 1948. A method of establishing groups of equal amplitude in plant sociology based on similarity of species content and its application to analyses of the vegetation on Danish commons. Vidensk. Selsk. Biol. Skr. 5, 1-34.

Spotila, J.R., Berman, E.R., 1976. Determination of skin resistance and the role of the skin in controlling water loss in amphibians and reptiles. Comp. Biochem. Physiol. A 55, 407-411.

SPSS, 2012. IBM SPSS Statistics 21. SPSS Inc., Chicago, IL, USA.

Trimble, G.R., 1977. A history of the Fernow Experimental Forest and the Parsons Timber and Watershed Laboratory. General Technical Report NE-28. USDA Forest Service, Northeastern Forest Experimental Station, Upper Darby, PA, p. 46.

Van Lear, D.H., Waldrop, T.A., 1989. History, uses and effects of fire in the Appalachians. General Technical Report SE-54. USDA Forest Service, Southeastern Forest Experiment Station, Asheville, NC, pp. 26.

White, G.C., Burnham, K.P., 1999. Program MARK: survival estimation for populations of marked animals. Bird Study 46 (Suppl.), 120-138.

Williams, B.K., Nichols, J.D., Conroy, M.J., 2002. Analysis and Management of Animal Populations. Academic Press, San Diego, California, USA. 